\title{
Nutrient content of water spinach (Ipomoea aquatica) under different harvesting stages and preservation methods in Zimbabwe
}

\author{
Hamunyari CHITSA, Tuarira MTAITA* and Jefta TABARIRA
}

Faculty of Agriculture and Natural Resources, Africa University, P.O. Box 1320, Mutare-Zimbabwe.

*Corresponding author; E-mail: tamtaita@africau.edu : Tél: +263-772 587604

\begin{abstract}
Water spinach is very perishable and it does not store well even in the refrigerator. It requires special processing treatments to reduce post-harvest losses. Nutrient content analysis of the water spinach (Ipomoea aquatica) was carried out at different harvest stages and under different preservation methods. Standard methods of food analysis were used. Water spinach was harvested at 3,4 and 5 weeks after transplanting (WAT). The preservation methods used were freezing after blanching, sun drying of vegetable samples without any pre-treatment and sun drying samples after blanching. Fresh water spinach samples were used as the control. The Ca concentrations were remarkably high in all preservation methods. Blanching increased the concentration of $\mathrm{Ca}, \mathrm{P}, \mathrm{Fe}, \mathrm{K}, \mathrm{Na}$ and $\mathrm{Mg}$ and decreased the concentration of $\mathrm{Pb}$. Freezing increased the concentration of $\mathrm{Ca}, \mathrm{P}, \mathrm{Na}$ and $\mathrm{Mg}$ and decreased the concentration of $\mathrm{Fe}, \mathrm{Pb}$ and $\mathrm{K}$. Sun drying increased the concentration for $\mathrm{Ca}, \mathrm{P}, \mathrm{Fe}, \mathrm{K}, \mathrm{Na}$ and $\mathrm{Mg}$ and decreased the concentration of $\mathrm{Pb}$. Blanching and sun drying of water spinach could be the best method of preserving it without conceding on its quality.

(C) 2014 International Formulae Group. All rights reserved.
\end{abstract}

Keywords: Ipomoea aquatica, blanching, sun-drying, freezing, nutrient analysis, different harvest stages.

\section{INTRODUCTION}

Vegetables generally form indispensable constituents of human diets supplying the body with minerals (Akindahunsi and Salawu, 2005). Micronutrient malnutrition, resulting from an imbalanced diet, is prevalent globally regardless of age, location, or income category, and is often the main cause of various debilitating chronic and fatal diseases. While 925 million people currently suffer from hunger, approximately 1.6 billion are malnourished (FAO, 2010; WHO, 2011).

Water spinach, also known as water convolvulus, kangkong, swamp cabbage, ongchoy, hung tsai and rawu muong is closely related to sweet potato, as well as morning glory. It is a climbing plant with large purple flowers that prefers damp conditions, flourishing along the banks of streams and boggy areas. The leaves are dark green and are usually long to heart-shaped, depending on variety. Practically, all parts of the young plant are edible, although the shoot tips and young leaves are preferred. Water spinach deteriorates rapidly once picked, so must always be used fresh. The leaves can be used whole, or cut into smaller pieces. Like ordinary spinach, the stems require slightly longer cooking than the leaves. In South China, India and Southeast Asia, water spinach is traditionally much appreciated as a 
leaf vegetable, having nutritional benefits similar to spinach.

Water spinach as a green leafy vegetable has the potential to supply the much needed minerals (Kala and Prakash, 2004). It is high in Vitamins A and C, has good quality protein and is rich in minerals, especially iron. As with many plants (Etkin 2006; Ogle et al., 2003), water spinach is considered a food with medicinal effects. Eaten in large quantities, water spinach can act as a mild laxative. It is recommended for piles, and in certain nervous conditions with sleeplessness and head-ache (Van Valkenburgh and Bunyapraphatsara, 2001).

Unlike some other green vegetables, water spinach is not bitter. It has a sweet, mild flavor. The young shoots and leaves are picked before the plant flowers to ensure good quality. However, nutrient loss occurs during all types of preservation (Barrett, 2007). Maturity at harvest influences the vegetable's quality. Delays between harvest and consumption or processing can result in losses of flavor and nutritional quality (Lee and Kader, 2000; MacEvilly and Peltola, 2003).

Despite all the appreciable uses of water spinach, this vegetable is not common in Zimbabwe and no work has been done on the nutritional content of water spinach at different harvest stages. The main objective of this research was to assess the nutritional content of water spinach at different harvest stages and under different preservation methods. Because there are many causes of post-harvest loss, this study will help in exploring the most effective nutrient-retaining preservation method appropriate for the water spinach vegetable at different harvesting stages.

\section{MATERIALS AND METHODS}

\section{Experimental site and location}

The study was carried out in the summer season from $27^{\text {th }}$ December 2013 to1 $5^{\text {th }}$ March, 2014. The experiment was carried out at Africa University, Mutare,
Zimbabwe. The area is located in the agro ecological natural region 1 of Zimbabwe. The site has an elevation of $1104 \mathrm{~m}$ above the sea level. Rainfall in this region is high (more than $1000 \mathrm{~mm}$ per annum in areas lying below $1700 \mathrm{~m}$ altitude), normally with some precipitation in all months of the year. Temperatures are normally comparatively low and the rainfall is consequently high (Moyo, 2000). The soil at the experimental site is of the Rhodic ferralsols with the red soils being dominant. The soil is loam, well drained with incorporated organic matter, friable and free from stones. The soil is permeable with moderate water holding capacity and a $\mathrm{pH}$ range of 7.8 .

\section{Experimental design and treatments}

The experiment was laid out in Randomized Complete Block Design (RCBD) and was replicated three times. The experimental plots comprised of 8 rows measuring $2 \mathrm{~m}$ long and spaced $0.25 \mathrm{~m}$ apart. Two outside rows were regarded as borders. The treatments comprised of three harvest stages at 3, 4, and 5 weeks after transplanting (WAT). At each harvest stage, the samples were sliced and then either dried without any pre-treatment; sun dried after blanching or frozen after blanching.

\section{Land preparation and crop establishment}

The land was ploughed and disked. The gross plot was $32.64 \mathrm{~m}^{2}$ and the net plot was $24 \mathrm{~m}^{2}$. Seeds were sown on December 27, 2013. Seedlings were transplanted on January 24, 2014 at a spacing of $20 \mathrm{~cm}$ between plants, $25 \mathrm{~cm}$ between rows. The distance between blocks was $1 \mathrm{~m}$ and the distance from the edges of the experimental block was $1 \mathrm{~m}$ on each side. Supplementary irrigation was applied whenever necessary.

\section{Plant sample collection protocol}

Samples were collected at 3,4 and 5 WAT from the 6 middle rows. For each harvest, 21 plants were collected by cutting 
off the whole plant at the ground level and mixed thoroughly, cleaned and preserved as per treatment.

\section{Preservation methods \\ Blanching}

Sliced water spinach foliage was wrapped in a mutton cloth and pre-heated for 5 minutes in boiling water $\left(100{ }^{\circ} \mathrm{C}\right)$. The foliage was then removed from the hot water and immersed in cold water for 5 minutes and then squeezed to remove excess water. Half of the blanched foliage was then sun dried for 3 days and the other half was frozen for 4 days before nutrient content analysis.

\section{Sun drying}

Fresh sliced foliage of water spinach was dried using the natural sun for 3days before nutrient content analysis.

\section{Foliar nutrient analysis}

The harvested samples were analyzed for $\mathrm{P}, \mathrm{Ca}, \mathrm{K}, \mathrm{Mg}, \mathrm{Na}, \mathrm{Fe}$ and $\mathrm{Pb}$ following the protocols outlined by AOAC (1996).

\section{Statistical analyses}

The data collected were analyzed using GENSTAT Version 8.0. The data were subjected to analysis of variance and means were separated using Fisher's least significant difference (LSD) test at $\mathrm{P}=0.05$.

\section{RESULTS}

\section{General observations}

Water spinach is a fast growing vegetable and can be harvested from 21-45 days after sowing by cutting at ground level or by once-over harvest. It is a tender trailing plant with a hollow stem up to $3 \mathrm{~m}$ long or more. The stem tips and foliage are succulent and light green. These are arrow head shaped and narrow. Flowers are white and light pink or purple, broadly funnel shaped, 'morning glory' like, and solitary from the leaf axis.

\section{Ca content}

As indicated in Table 1, there were significant differences $(\mathrm{p}<0.05)$ in $\mathrm{Ca}$ content in all preservation methods from 3 to 5 WAT. Sun drying reading was highest (23254.05 $\mathrm{mg} / \mathrm{kg}$ ) followed by freezing $(23254 \mathrm{mg} / \mathrm{kg})$. An increase in the levels of $\mathrm{Ca}$ from 3 to 5 WAT was observed for the control and sun dried. No significant difference $(p>0.05)$ was detected at 3 WAT between the control and freezing.

\section{Phosphorous content}

The concentration of $\mathrm{P}$ at different harvest stages and under different preservation methods was significantly different $(\mathrm{p}<0.05)$. As indicated in Table 3, the highest concentration of $\mathrm{P}$ was observed in sun drying and blanched samples at 3 WAT.

\section{Fe content}

The sun drying and freezing recorded the highest and lowest levels of $\mathrm{Fe}$ respectively. There were significant differences $(\mathrm{p}<0.05)$ in $\mathrm{Fe}$ concentration between all methods at 4 to 5 WAT. No significant difference $(\mathrm{p}>0.05)$ was observed between freezing, sun drying and blanching at 3 WAT (Table 3).

\section{$K$ content}

There were significant differences $(\mathrm{p}<0.05)$ in $\mathrm{K}$ content in all preservation methods from 3 to 5 WAT. Sun drying was highest followed by blanching. As indicated in Table 4, the levels of $\mathrm{K}$ decreased from 3 to 5 WAT irrespective of the method.

\section{Na content}

There were no significant differences $(p>0.05)$ in $\mathrm{Na}$ concentration at different harvest stages and under different preservation methods except for sun drying and blanching at stage 3 . The highest $\mathrm{Na}$ concentration of $8726.19 \mathrm{mg} / \mathrm{kg}$ was reached at $3 \mathrm{WAT}$. There 
were significant differences $(\mathrm{p}<0.05)$ amongst the different stages and preservation methods. However, there were no significant differences $(p>0.05)$ between sun dried and control on the 3 WAT (Table 6).

\section{Pb content}

Table 7 shows that there were significant differences $(p<0.05)$ in the concentration of lead at different harvest stages and under different harvest stages. The highest lead concentration was recorded in fresh weight and lowest in freezing method. There was no significant difference $(p>0.05)$ between freshly harvested and frozen water spinach at stage 4. There was also no significant difference in lead concentration between stage 5 sun drying and stage 3 blanched water spinach.

Table 1: Mean concentration of calcium $(\mathrm{mg} / 100 \mathrm{~g})$ control and dry weight for three preservation methods at three different harvest stages.

\begin{tabular}{|c|c|c|c|c|c|c|}
\hline \multirow{2}{*}{$\begin{array}{l}\text { Stage } \\
\text { (WAT) }\end{array}$} & \multicolumn{4}{|c|}{ Preservation methods } & \multirow[t]{2}{*}{ LSD } & \multirow[t]{2}{*}{$P$ value } \\
\hline & Control & $\mathbf{F Z}$ & SD & BL & & \\
\hline 3 & $851.62^{b}$ & $538.83^{\mathrm{c}}$ & $3144.00^{c}$ & $6925.14^{\mathrm{c}}$ & 751.8 & $*$ \\
\hline 4 & $1040.07^{\mathrm{b}}$ & $23254.05^{\mathrm{a}}$ & $12384.90^{\mathrm{b}}$ & $14257.02^{\mathrm{a}}$ & & \\
\hline 5 & $8443.47^{\mathrm{a}}$ & $20205.89^{b}$ & $26735.00^{\mathrm{a}}$ & $10119.57^{\mathrm{b}}$ & 751.8 & $*$ \\
\hline Mean & 3445.05 & 14666.26 & 14087.97 & 10433.91 & & \\
\hline $\mathrm{P}$ value & $*$ & $*$ & $*$ & $*$ & & \\
\hline $\operatorname{LSD}_{(0.05)}$ & 751.80 & 751.80 & 751.80 & 751.80 & & \\
\hline $\mathrm{CV}_{(\%)}$ & 5.50 & 5.50 & 5.50 & 5.50 & & \\
\hline
\end{tabular}

Table 2: Mean concentration of phosphorus (mg/100g) control and dry weight for three preservation methods at three different harvest stages.

\begin{tabular}{|c|c|c|c|c|c|c|}
\hline \multirow{2}{*}{$\begin{array}{l}\text { Stage } \\
(\mathbf{W A T})\end{array}$} & \multicolumn{4}{|c|}{ Preservation methods } & \multirow[t]{2}{*}{ LSD } & \multirow[t]{2}{*}{$P$ value } \\
\hline & Control & FZ & SD & BL & & \\
\hline 3 & $1700.31^{\mathrm{b}}$ & $9079.81^{\mathrm{a}}$ & $9792.29^{\mathrm{a}}$ & $9736.67^{\mathrm{a}}$ & 40.84 & $*$ \\
\hline 4 & $1362.98^{c}$ & $443.12^{c}$ & $2882.85^{\mathrm{c}}$ & $3893.44^{\mathrm{b}}$ & 40.84 & \\
\hline 5 & $4496.28^{\mathrm{a}}$ & $55.91^{\mathrm{b}}$ & $5600.78^{b}$ & $2381.83^{c}$ & 40.84 & $*$ \\
\hline Mean & 2519.93 & 3360.91 & 6092.03 & 5337.34 & & \\
\hline $\mathrm{P}$ value & $*$ & $*$ & $*$ & $*$ & & \\
\hline $\operatorname{LSD}_{(0.05)}$ & 40.84 & 40.84 & 40.84 & 40.84 & & \\
\hline $\mathrm{CV}_{(\%)}$ & 0.60 & 0.60 & 0.60 & 0.60 & & \\
\hline
\end{tabular}


Table 3: Mean concentration of iron $(\mathrm{mg} / 100 \mathrm{~g})$ control and dry weight for three preservation methods at three different harvest stages.

\begin{tabular}{|c|c|c|c|c|c|c|}
\hline \multirow{2}{*}{$\begin{array}{l}\text { Stage } \\
\text { (WAT) }\end{array}$} & \multicolumn{4}{|c|}{ Preservation methods } & \multirow[t]{2}{*}{ LSD } & \multirow[t]{2}{*}{$P$ value } \\
\hline & Control & FZ & SD & BL & & \\
\hline 3 & $7.98^{\mathrm{b}}$ & $0.01^{\mathrm{b}}$ & $0.40^{\mathrm{c}}$ & $0.10^{\mathrm{c}}$ & 0.47 & $*$ \\
\hline 4 & $2.83^{\mathrm{c}}$ & $4.31^{\mathrm{a}}$ & $39.66^{\mathrm{a}}$ & $39.66^{\mathrm{a}}$ & 0.47 & * \\
\hline 5 & $26.46^{\mathrm{a}}$ & $4.22^{\mathrm{a}}$ & $23.87^{\mathrm{b}}$ & $34.37^{\mathrm{b}}$ & 0.47 & $*$ \\
\hline Mean & 12.42 & 2.85 & 30.67 & 24.71 & & \\
\hline$P$ value & $*$ & $*$ & $*$ & $*$ & & \\
\hline $\operatorname{LSD}_{(0.05)}$ & 0.47 & 0.47 & 0.47 & 0.47 & & \\
\hline $\mathrm{CV}_{(\%)}$ & 1.60 & 1.60 & 1.60 & 1.60 & & \\
\hline
\end{tabular}

Table 4: Mean concentration of potassium $(\mathrm{mg} / 100 \mathrm{~g})$ control and dry weight for three preservation methods at three different harvest stages.

\begin{tabular}{|c|c|c|c|c|c|c|}
\hline \multirow{2}{*}{$\begin{array}{l}\text { Stage } \\
\text { (WAT) }\end{array}$} & \multicolumn{4}{|c|}{ Preservation methods } & \multirow[t]{2}{*}{ LSD } & \multirow[t]{2}{*}{ P value } \\
\hline & Control & FZ & SD & BL & & \\
\hline 3 & $3957.30^{\mathrm{a}}$ & $1868.11^{\mathrm{a}}$ & $32322.59^{\mathrm{a}}$ & $23312.11^{\mathrm{a}}$ & 143.60 & * \\
\hline 4 & $2326.02^{\mathrm{b}}$ & $1595.11^{\mathrm{b}}$ & $617.77^{\mathrm{b}}$ & $736.71^{\mathrm{b}}$ & 143.60 & * \\
\hline 5 & $812.35^{\mathrm{c}}$ & $1345.43^{\mathrm{c}}$ & $573.70^{\mathrm{c}}$ & $421.83^{\mathrm{c}}$ & 143.60 & $*$ \\
\hline Mean & 2365.22 & 1602.88 & 11171.35 & 8156.09 & & \\
\hline$P$ value & * & * & $*$ & $*$ & & \\
\hline $\operatorname{LSD}_{(0.05)}$ & 143.60 & 143.60 & 143.60 & 143.60 & & \\
\hline$C V_{(\%)}$ & 1.50 & 1.50 & 1.50 & 1.50 & & \\
\hline
\end{tabular}

Table 6: Mean concentration of magnesium $(\mathrm{mg} / 100 \mathrm{~g})$ control and dry weight for three preservation methods at three different harvest stages.

\begin{tabular}{|c|c|c|c|c|c|c|}
\hline \multirow{2}{*}{$\begin{array}{l}\text { Stage } \\
\text { (WAT) }\end{array}$} & \multicolumn{4}{|c|}{ Preservation methods } & \multirow[t]{2}{*}{ LSD } & \multirow[t]{2}{*}{$P$ value } \\
\hline & Control & FZ & SD & BL & & \\
\hline 3 & $279.98^{b}$ & $152.41^{b}$ & $1007.19^{\mathrm{a}}$ & $2134.15^{\mathrm{a}}$ & 17.84 & $*$ \\
\hline 4 & $319.33^{\mathrm{a}}$ & $7.19^{c}$ & $178.44^{\mathrm{b}}$ & $479.40^{\mathrm{b}}$ & 17.84 & $*$ \\
\hline 5 & $94.14^{\mathrm{c}}$ & $357.32^{\mathrm{a}}$ & $96.73^{\mathrm{c}}$ & $124.57^{\mathrm{c}}$ & 17.84 & $*$ \\
\hline Mean & 231.10 & 329.70 & 370.40 & 124.57 & & \\
\hline $\mathrm{P}$ value & $*$ & $*$ & $*$ & $*$ & & \\
\hline $\operatorname{LSD}_{(0.05)}$ & 17.84 & 17.84 & 17.84 & 17.84 & & \\
\hline $\mathrm{CV}_{(\%)}$ & 2.40 & 2.40 & 2.40 & 2.40 & & \\
\hline
\end{tabular}


Table 7: Mean concentration of lead $(\mathrm{mg} / 100 \mathrm{~g})$ control and dry weight for three preservation methods at three different harvest stages.

\begin{tabular}{|c|c|c|c|c|c|c|}
\hline \multirow[t]{2}{*}{ Stage (WAT) } & \multicolumn{4}{|c|}{ Preservation methods } & \multirow[t]{2}{*}{ LSD } & \multirow[t]{2}{*}{$P$ value } \\
\hline & Control & FZ & SD & BL & & \\
\hline 3 & $7.50^{\mathrm{b}}$ & $0.17^{\mathrm{c}}$ & $0.29^{\mathrm{c}}$ & $1.22^{\mathrm{c}}$ & 0.30 & * \\
\hline 4 & $0.73^{\mathrm{c}}$ & $0.62^{\mathrm{a}}$ & $3.49^{\mathrm{a}}$ & $2.68^{\mathrm{b}}$ & 0.30 & $*$ \\
\hline 5 & $14.79^{\mathrm{a}}$ & $0.28^{\mathrm{b}}$ & $1.28^{\mathrm{b}}$ & $4.67^{\mathrm{a}}$ & 0.30 & $*$ \\
\hline Mean & 7.68 & 0.36 & 1.69 & 2.86 & & \\
\hline$P$ value & $*$ & $*$ & $*$ & $*$ & & \\
\hline $\operatorname{LSD}_{(0.05)}$ & 0.30 & 0.30 & 0.30 & 0.30 & & \\
\hline $\mathrm{CV}_{(\%)}$ & 5.60 & 5.60 & 5.60 & 5.60 & & \\
\hline
\end{tabular}

\section{DISCUSSION}

Calcium and phosphorous are associated with each other for development and proper functioning of bones, teeth and muscles (Turan et al., 2003). The calcium content obtained from different treatments $(344.505 ; 1466.26 ; 1408.797$ and 1043.391 $\mathrm{mg} / 1000 \mathrm{~g}$ respectively) was higher than that recorded for the Vietnamese Ipomoea aquatica leaves $(101 \mathrm{mg} / 100 \mathrm{~g})$ (Ogle et al., 2001). The higher values might be attributed to the fact that in this experiment both the stems and the leaves were analyzed together.

Significant differences $(\mathrm{p}<0.05)$ in the concentration of $\mathrm{P}$ at different harvest stages and under different preservation methods were eminent. According to Guil-Guerrero et al. (1998), for good calcium and phosphorus intestinal utilization, $\mathrm{Ca} / \mathrm{P}$ ratio must be close to a unity. However, the freezing, sun dried and blanched had high ratios $(4.36 ; 2.31$ and 1.95 respectively) as compared to the control (1.37) a clear indication that the leaves are good sources of Ca over that of P.

The highest and lowest levels of $\mathrm{Fe}$ were recorded for sun dried and freezing respectively. The findings on iron content were $12.42,28.48,30.669$ and $24.713 \mathrm{mg} / 100$ $\mathrm{g}$ for the control, freezing, and sun dried and blanched samples respectively. This is in agreement with the values reported when similar work was done in Vietnam (Ogle et al., 2001). However, an outstanding finding of $212.47 \mathrm{mg} / 100 \mathrm{~g}$ was made on iron content in the leaves of Ipomoea aquatic (Umar et al. 2007) which might be attributed to soil contamination (Gowda et al., 2004).

The results obtained for the control, sun dried and blanched show that the methods retain adequate nutrients for all age groups as the average daily dietary intake (DDI) level of the iron nutrient considered sufficient by the Food and Nutrition Board (2001) to meet the requirements of $97.5 \%$ of healthy individuals in each life-stage and sex group is $8 \mathrm{mg}$. However, the results for freezing are lower than the recommended DDI and consequently the diet based on this vegetable may require to be supplemented with other food material rich in iron. The tolerable upper limit for iron is 45 $\mathrm{mg}$ /day meaning that no method is retaining nutrients at a concentration harmful to people.

As indicated in Table 4, the levels of $\mathrm{K}$ decreased from 3 to 5 WAT irrespective of the method. However, the amounts retained from sun drying and blanching (11171.35 and $8156.09 \mathrm{mg}$ respectively) are adequate to meet the recommended $4700 \mathrm{mg}$ average DDI. In the similar work, Umar et al. (2007) obtained a value of $5,458.33 \mathrm{mg} / 100 \mathrm{~g}$ which is higher than the values obtained from the control and freezing.

Significant amounts of $\mathrm{Na}$ were retained by the different preservation 
methods. Similar to the findings by Umar et al. (2007), the concentration of $\mathrm{Na}$ from this study were found to be $560.87 \mathrm{mg} / 100 \mathrm{~g}$ in the control and $1008.55 \mathrm{mg} / 1000 \mathrm{~g}, 2938.02$ $\mathrm{mg} / 1000 \mathrm{~g}$ and $3080.39 \mathrm{mg} / 1000 \mathrm{~g}$ in the freezing, sun drying and blanched respectively. Appropriate $\mathrm{K} / \mathrm{Na}$ ratios (4.21; $1.58 ; 3.80$ and 2.65 for the control, freezing, sun drying and blanching respectively) are important in any vegetable because potassium depresses while sodium enhances blood pressure. This is an important factor in prevention of hypertension and atherosclerosis (Yoshimura et al., 1991). From the result, the concentration of potassium was greater than that of sodium (Tables 4 and 5). Oshodi et al. (1999) attributes the high levels of potassium in vegetables to its abundance in some soils depending on the locality.

The concentrations of $\mathrm{Mg}$ retained under the control, freezing, sun dried and blanched were 231.1; 329.7; 370.4 and 812.4 $\mathrm{mg} / 100 \mathrm{~g}$ respectively. High $\mathrm{Mg}$ concentration is expected since $\mathrm{Mg}$ is a component of chlorophyll (Akwaowo et al., 2000). The values obtained in this study concur with findings by Umar et al. (2007) who found $\mathrm{Mg}$ concentration of $312.69 \mathrm{mg} / 100 \mathrm{~g}$ in water spinach. The concentrations for $\mathrm{Mg}$ in the control, sun dried and freezing are in the same range with those found by Thangadari et al. (2001). The results obtained for $\mathrm{Mg}$ were high despite the presence of high levels of lead that has inhibitory influence on enzymatic reactions, disturbs metabolism and replace essential metals, such as $\mathrm{Mg}$ in chlorophyll. The DDI of $\mathrm{Mg}$ for the adults, children and pregnant women are 550, 170 and $375 \mathrm{mg}$ respectively. This means that all the preservation methods retained nutrients, nutritionally adequate for all age groups.

The highest lead concentration was recorded in the fresh water spinach and lowest in frozen samples (Table 7). Metals occur naturally in the environment at low levels and are present in soil sediment, water, air and biota. The highest concentrations for $\mathrm{Pb}$ recorded at 5 WAT for the control and blanched might be attributed to its slow biological turnover rate.

\section{Conclusion}

Blanching resulted in a significant increase in the concentration of $\mathrm{Ca}, \mathrm{P}, \mathrm{Fe}, \mathrm{K}$, $\mathrm{Na}$ and $\mathrm{Mg}$ and a significant decrease in $\mathrm{Pb}$. Freezing increased the concentration of $\mathrm{Ca}, \mathrm{P}$, $\mathrm{Na}$ and $\mathrm{Mg}$ and decreased the concentration of $\mathrm{Fe}, \mathrm{Pb}$ and $\mathrm{K}$. Sun drying increased the concentration for $\mathrm{Ca}, \mathrm{P}, \mathrm{Fe}, \mathrm{K}, \mathrm{Na}$ and $\mathrm{Mg}$ and decreased the concentration of $\mathrm{Pb}$. The $\mathrm{Pb}$ reduction is of advantageous to consumers as the mineral is detrimental. Since blanching, followed by sun drying present some advantages over the straight sun drying; such as increase in $\mathrm{Na}$ and $\mathrm{Mg}$ concentration, water spinach should be blanched and then sun dried for preservation.

\section{REFERENCES}

Akindahunsi AA, Salawu SO. 2005. Phytochemical Screening and nutrientanti nutrient composition of selected tropical green leafy vegetables. Afr. J. Biotech., 4: 497-501.

Akwaowo EU, Ndon BA, Etuk EU. 2000. Minerals and antinutrients in fluted pumpkin (Telfaria occidentalis Hook F.). Food Chem., 70: 235-240.

AOAC. 1996. Official Methods of Analysis $\left(14^{\text {th }}\right.$ edn). Association of Analytical Chemists: Washington, D.C.

Food and Agricultural Organisation, of United Nations. 2010. FAO Fertilizer and Plant Nutrition Bulleting, FAO, 19.

Food and Nutrition Board. 2001. Institute of Medicine. Dietary Reference Intakes: Vitamin. A, Vitamin K, Arsenic, Boron, Chromium, Copper, Iodine, Iron, Manganese, Molybdenum, Nickel, Silicon, Vanadium, and Zinc. National Academy Press: Washington, D.C.

Gowda NKS, Rammana JV, Prasad CS, Sing K. 2004. Micronutrient content of certain tropical conventional and unconventional feed resources of Southern India. Trop. Anim. Health Prod., 36: 77-94. 
Guil-Guerrero JL, Gimenez-Gimenez A, Rodriguez-Garcia I, Torija-Isasa ME. 1998. Nutritional composition of Sonchus species (S. asper L., S. oleraceus L. and S. tenerrimus L.). J. Sci. Food Agric., 76: 628-632.

Kala A, Prakash J. 2004. Nutrient composition and sensory profile of differently cooked green leafy vegetables. Inlt. J. food Properties, 7: 659-669.

Lee SK, Kader AA. 2000. Pre-harvest and postharvest factors influencing vitamin $\mathrm{C}$ content of horticultural crops. Post-harv. Biol. Technol., 20: 207-220.

MacEvilly C, Peltola K. 2003. The effect of agronomy storage processing and cooking on bioactive substances in food. In Plants: Diet and Health, Goldberg G (ed). Blackwell Publishing Ltd.: Oxford, U.K.; 226-239.

Moyo S. 2000. Zimbabwe Environmental Dilemma: Balancing Resource Inequities. Environmental Research Organization: Harare, Zimbabwe; 161.
Oshodi AA, Ipinmoroti KO, Fagbemi TN. 1999. Chemical composition, amino acid analysis and fuctional properties of breadnut (Artocarpusaltilis) flour. Nahrung Food, 43: 402-405.

Setiawan L. 1996. Effect of Tribulusterestris L. on Sperm Morphology. Airlangga University: Surabaya, Indonesia.

Turan M, Kordali S, Zengin H, Dursun A, Sezen Y. 2003. Macro and micro mineral content of some wild edible leaves consumed in Eastern Anatolia. Acta Agric. Scand. Sect. B: Plant Soil Sci., 53: 129-137.

Umar K, Hassan LG, Dangoggo SM, Ladan MJ. 2007. Nutritional Composition of Water Spinach (Ipomoea aquatic Forsk.) Leaves. Journal of Applied Sciences, 7: 803-809.

Yoshimura M, Takahashi H, Nakanishi T, 1991. Role of sodium, potassium, calcium, magnesium on blood pressure regulation. An antihypertensive dietary therapy. Jpn. J. Nutr., 49: 53-62. 